\title{
Pengaruh Nilai Iklan yang Dipersepsikan dan Getok Tular terhadap Minat Wisata Kota Yogyakarta Dimediasi oleh Citra Destinasi
}

\author{
Mustika Syarifuddin \\ Program Pascasarjana Institut Seni Indonesia Yogyakarta \\ mustikasyarifuddin20031991@gmail.com
}

\begin{abstract}
Abstrak
Penelitian ini bertujuan untuk menguji pengaruh nilai iklan yang dipersepsikan dan getok tular (wom) terhadap minat wisata kota di Kota Yogyakarta dengan dimediasi oleh citra destinasi. Penelitian ini dilakukan di Kota Yogyakarta dengan mensurvei 386 responden wisatawan domestik. Teknik pengambilan sampelnya dengan sistem acak menggunakan sampling daerah (cluster). Metode analisis datanya menggunakan analisis regresi sederhana bertahap dan analisis mediasi. Hasil penelitian ini menemukan adanya pengaruh signifikan dan positif antara nilai iklan yang dipersepsikan dan getok tular terhadap citra destinasi. Penelitian ini menunjukkan pula bahwa adanya pengaruh signifikan secara langsung maupun tidak langsung antara nilai iklan yang dipersepsikan dan getok tular terhadap minat wisata Kota Yogyakarta melalui citra destinasi sebagai variabel pemediasi komplementer.

Kata kunci: nilai iklan yang dipersepsikan, getok tular, citra destinasi, minat wisata
\end{abstract}

\begin{abstract}
The purpose of this study was to examine the influences of perceived advertising value and word of mouth on intentions of city visit Yogyakarta is mediating by destination image. This research was conducted in the city of Yogyakarta with 386 respondents by surveying domestic tourists. Sample collection techniques with a system using a random sampling area (cluster). Methods of data analysis using stages of simple regression and mediation analysis. The results of this study found a significant and positive influence between perceived advertising value and word of mouth on the destination image. This study also shows that significant influence, directly or indirectly between it perceived value advertising and word of mouth to the intentions of city visit Yogyakarta through the destination image as a variable complementary mediator.
\end{abstract}

Keywords: perceived advertising value, word of mouth, destination image, intention to visit

\section{Pendahuluan}

Industri pariwisata Indonesia saat ini bertumpu pada potensi budaya sekitar 60 persen dan 35 persen potensi alam serta 5 persen pada potensi man made. Potensi budaya akan dikembangkan pada produk wisata heritage dan religi, wisata kuliner dan belanja, serta wisata kota dan desa (Kedaulatan Rakyat, 2015: 11). Salah satu jenis wisata yang menjadi sumber pendapatan asli daerah yakni wisata kota. Hasil survei litbang Kompas (2015) bahwa jenis wisata lain yang banyak diminati wisatawan domestik yakni wisata kota yang secara umum mengeksplorasi suatu kota, berikut dengan keunikan dan kekhasan yang ada, seperti balai kota dan alun-alun, ruas jalan tertentu yang memiliki keunikan dan ciri khas tersendiri, 
monumen penanda sejarah kota, dan kuliner khas suatu daerah yang menjadi daya tarik. Tantangan pengembangan potensi budaya perkotaan yakni memahami sisi permintaan pasar dengan memahami keinginan dan perilaku wisatawan. Para marketer (marketing) dituntut memahami faktor-faktor yang dapat mempengaruhi dalam memilih objek destinasi guna mempermudah mempromosikan produk wisata dan mendongkrak tingkat kunjungan wisatawan.

Di Indonesia, tujuan wisata kota masih terfokus pada beberapa kota saja, belum merata pada kota-kota lainnya. Hal ini dilihat dari hasil gambaran makro pariwisata nasional bahwa ada tiga pilihan berwisata pasar wisatawan nusantara yakni DKI Jakarta, Bali, dan DI Yogyakarta (Ditjen Pemasaran Depbudpar dalam Damanik, 2013: 159). Sasaran kota-kota yang dikunjungi yakni ketiga provinsi tersebut sehingga dapat ditarik kesimpulan, bahwa diluar dari ketiga provinsi tersebut masih kurang peminatnya sehingga perlu upaya pemerataan dan promosi untuk tiap daerah. Hal ini bertujuan memajukan pariwisata di berbagai daerah sebagai peningkatan taraf ekonomi Indonesia.

Salah satu kota dari provisi tersebut yang berhasil menarik wisatawan domestik sebagai kota favorit yakni Kota Yogyakarta. Hal tersebut dibuktikan dengan hasil laporan statistik data kunjungan wisatawan ke provinsi DIY tahun 2014 sebagai berikut:

Tabel 1. Daftar jumlah kunjungan wisatawan di Provinsi DIY tahun 2014

\begin{tabular}{|c|l|r|r|c|}
\hline \multirow{2}{*}{ No } & \multicolumn{2}{|c|}{ ODTW } & \multicolumn{3}{c|}{ Tahun 2014 } \\
\cline { 3 - 5 } & & Wisman & Wisnus & Jumlah \\
\hline 1 & Kota Yogyakarta & 226.197 & 5.025 .155 & 5.251 .352 \\
\hline 2 & Kabupaten Sleman & 340.559 & 3.883 .359 & 4.223 .958 \\
\hline 3 & Kabupaten Bantul & 502 & 2.708 .314 & 2.708 .816 \\
\hline 4 & Kabupaten Kulon Progo & - & 904.972 & 904.972 \\
\hline 5 & Kabupaten Gunung Kidul & 5.319 & 3.679 .818 & 3.685 .137 \\
\hline \multicolumn{2}{|l}{ Jumlah Kunjungan Wisatawan di Provinsi DIY } & 572.617 & 16.201 .618 & 16.774 .235 \\
\hline
\end{tabular}

Sumber: Data diambil dari buku statistik pariwisata 2014 (halaman 59).

Berdasarkan data tersebut menunjukkan kota yang menjadi sasaran wisatawan domestik atau wisatawan nusantara (wisnus) di provinsi DIY yakni Kota Yogyakarta. Pengaruh tingkat kunjungan wisatawan yang tinggi dapat dipengaruhi beberapa faktor. Sehingga dengan memahami pengaruh terhadap minat wisatawan yang berkunjung ke Kota Yogyakarta akan memudahkan untuk menarik wisatawan di kota lainnya.

Menurut Woodside dan Lysonski (dalam Gibson, 2008) yang mengemukakan bahwa niat berwisata merupakan konsekuensi dari dua variabel eksogen yakni karakteristik wisatawan dan pengaruh pemasaran. Salah satu upaya pemasaran yang dilakukan oleh pihak pemerintah dan para marketer yakni kegiatan promosi wisata melalui iklan lewat berbagai media yang membutuh biaya yang tinggi. Mengingat biaya yang dikeluarkan tinggi, maka penting diketahui seberapa efektif iklan tersebut. Iklan yang efektif mampu menyampaikan informasi dan ditangkap oleh wisatawan yang berdampak pada kesan atau citra pada destinasi tersebut. Nilai iklan yang tersampaikan akan dipersepsikan berbeda pada setiap wisatawan.

Madasu (2013) yang mengemukakan bahwa iklan merupakan bagian dari aktivitas promosi untuk mengkomunikasikan produk dan membujuk target konsumen-konsumennya 
untuk membelinya sedangkan komunikasi word of mouth atau dikenal dengan istilah getok tular merupakan interaksi utama wisatawan. Peneliti lainnya menemukan bahwa word of mouth berpengaruh positif terhadap minat berwisata (Zarrad \& Debabi, 2015; Miao, 2014; Jalilvand \& Samiei, 2012; Di Pietro dan Di Virgilio, 2012; Fakharyan et al, 2012). Adapun penelitian lainnya mencoba mengeksplorasi hubungan antara pengaruh iklan dan minat berwisata akan keputusan membeli produk wisata (Al-Ekam et. al, 2012). Bahkan ada pula yang menguraikan pengaruh citra destinasi terhadap minat wisatawan (Mohammed et al; 2014, Gibson et al; 2008).

Penelitian-penelitian dahulu berfokus pada variabel word of mouth, iklan, dan citra destinasi, namun belum ada yang menguraikan kaitan ketiga variabel tersebut terhadap minat berwisata kota khususnya di Indonesia. Sehingga penelitian ini untuk menguji secara bersamaan ketiga variabel tersebut yang batasan penelitian ini fokus pada variabel nilai iklan promosi wisata di media yang dipersepsikan, getok tular, citra destinasi terhadap minat wisata Kota Yogyakarta yang mana Kota Yogyakarta sebagai salah satu kota yang berhasil menarik wisatawan domestik. Adapun permasalahan yang diangkat adalah bagaimanakah pengaruh nilai iklan yang dipersepsikan dan getok tular terhadap minat wisata kota Yogyakarta melalui citra destinasi sebagai variabel mediasi. Adapun hipotesisnya yakni nilai iklan yang dipersepsikan dan getok tular berpengaruh secara signifikan terhadap citra destinasi. Hipotesis kedua yakni variabel nilai iklan yang dipersepsikan dan getok tular melalui citra destinasi berpengaruh secara signifikan terhadap minat wisata kota.

\section{Tinjauan Pustaka}

Smith (dalam Damanik, 2013:110) secara khusus membuat tipologi wisatawan budaya yang terdiri dari wisatawan penggemar budaya kota (urban cultural tourist). Mereka secara khusus sangat tertarik pada situs sejarah, kota-kota baru, pembangunan rekreasi air, seni dan atraksi heritage, belanja dan kehidupan malam (Murphy dan Boyle dalam Damanik, 2013: 111).

Dalam industri pariwisata, identitas sebuah destinasi dikenal sebagai citra destinasi. Konsep citra destinasi didefinisikan oleh Lawson dan Baud Bovy tahun 1977 (dalam Lopes, 2011) sebagai ekspresi dari keseluruhan pemikiran secara objektif tentang pengetahuan, prasangka, imajinasi, dan emosional seseorang atau grup (sekelompok orang) terhadap sebuah keterangan (particular) lokasi/tempat.

Efektivitas dari iklan bisa diukur dari perspektif konsumen dengan mempelajari nilai iklan yang dirasakan oleh konsumen atau sikap mereka (Ajzen, 1991). Dalam kata lain, evaluasi kredibilitas iklan atau nilai iklan mampu mempengaruhi sikap seseorang untuk berperilaku.

Penelitian yang dilakukan oleh Xiaoli wang (2010), nilai iklan meliputi informatif, gangguan dan hiburan yang berdampak pada sikap terhadap iklan. Semakin tinggi sikap positif terhadap iklan semakin tinggi pula peluang niat untuk berperilaku. Dalam penelitian ini, persepsi terhadap iklan merupakan komponen dari nilai iklan baik dari segi informatifnya maupun dari segi hiburannya. 


\section{Metode Penelitian}

Metode yang digunakan yaitu metode kuantitatif dengan pendekatan survei. Adapun jenis penelitian ini adalah explanatory research dengan objek penelitian yakni minat wisatawan terhadap wisata kota yang melihat pengaruh nilai iklan yang dipersepsikan dan getok tular serta pengaruh mediasi citra destinasi. Sedangkan subjek yang diteliti adalah wisatawan domestik atau nusantara yang bukan masyarakat lokal Kota Yogyakarta. Lokasi penelitian dilakukan di Kota Yogyakarta, Provinsi Daerah Istimewa Yogyakarta yang berlangsung pada bulan Mei sampai dengan bulan Oktober 2016. Wilayah yang terpilih tempat pengambilan sampel ada 7 kecamatan dari total 14 kecamatan yang diambil dari table sampling yang tersebar merata di kota Yogyakarta.

Instrumen penelitian ini yakni kuesioner. Data yang akan dikumpulkan berupa data primer dari hasil kuesioner serta data sekunder mengenai data jumlah wisatawan di kota Yogyakarta bersumber data statistik pemerintah kota Yogyakarta serta peta kota Yogyakarta. Instrumen survei ini terdiri dari lima bagian yakni pada bagian pertama merupakan informasi demografi responden sampel penelitian ini yang meliputi jenis kelamin, usia, pendidikan, pendapatan, asal daerah, dan pekerjaan.

Pada bagian kedua yakni mengukur dimensi variabel nilai iklan yang dipersepsikan, pada bagian ketiga yakni mengukur dimensi variabel citra destinasi, sedangkan bagian keempat mengukur dimensi variabel getok tular dan yang terakhir bagian kelima yakni mengukur minat wisata kota para responden.

Komponen item variabel dalam penelitian ini diperoleh dari konsep dan teori serta beberapa penelitian terdahulu yang dimodifikasi dan disesuaikan dengan konteks penelitian ini. Variabel independen dalam penelitian ini ada 2 (dua) variabel yakni variabel nilai iklan yang dipersepsikan dengan 9 item pertanyaan dan variabel getok tular yang dijabarkan ke dalam indikator-indikator pertanyaan sebanyak 4 item. Selajutnya ada satu variabel antara atau mediasi yakni variabel citra destinasi yang penjabaran pertanyaannya sebanyak 10 item. Adapun variabel dependennya yakni variabel minat wisata dengan 3 item pertanyaan. Total keseluruhan item pertanyaan adalah sebanyak 26 pertanyaan.

Adapun sampel yang diambil menggunakan sample size calculator sebanyak 386 responden dengan confidence level (tingkat kepercayaan) $95 \%$ dan confidence interval sebanyak 5. Dari 386 responden, seperduanya didominasi oleh perempuan sebesar $55 \%$ dan laki-laki sebesar 45\%, rentang usia yang mendominasi dalam penelitian ini antara usia 20-29 tahun dengan tingkat persentase 51\%, disusul usia $\leq 19$ tahun sebanyak 20\%, 30-39 tahun sebanyak 19\%, 40-49\% sebanyak $6 \%$ dan $\geq 50$ tahun sebanyak 4\%. Adapun pendidikan terakhir yang ditempuh responden mayoritas yakni SMA sederajat. Sedangkan untuk kategori tingkat pendapatan wisatawan domestik mayoritas berpenghasilan sekitar kurang dari Rp 2.000.000,- yang berasal terbanyak dari daerah yang ada di pulau Jawa dengan didominasi oleh yang masih berstatus sebagai pelajar atau mahasiswa. 


\section{Analisis Data}

Analisis deskriptif data variabel dilakukan untuk mengetahui atau menggambarkan secara umum tanggapan responden terhadap variabel penelitian nilai iklan yang dipersepsikan, getok tular, citra destinasi dan minat wisata kota. Selanjutnya, dilakukan analisis regresi linear sederhana secara bertahap guna mengetahui pengaruh antar variabel. Dilakukan uji t guna menguji hipotesis. Kemudian dilakukan analisis mediasi menggunakan dasar kriteria yang dilakukan oleh Zhao et al (2010) guna menguji pengaruh langsung dan pengaruh tidak langsung melalui variabel mediasi. Berikut gambar model mediasi menurut Zhou et al (2010) sebagai berikut:

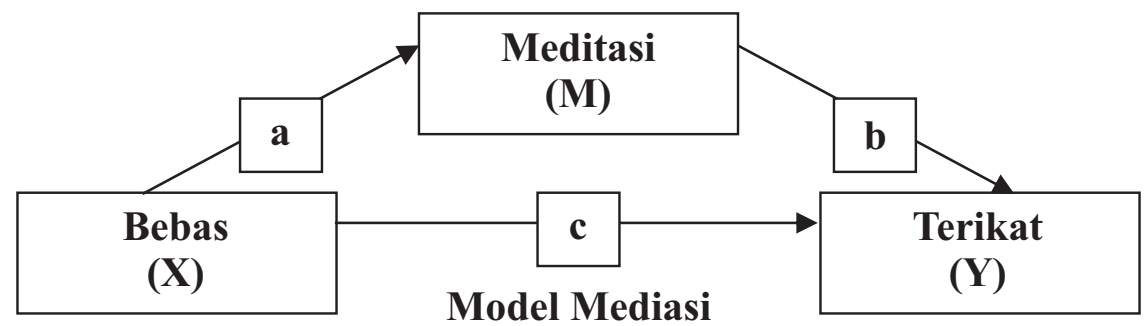

Sumber: Zhao et al, (2010)

Berikut ketentuan membangun mediasi dan tipenya menurut Zhao, et al. 2010: Apabila $\beta$ (a) dikali $\beta(b)$ signifikan dan $\beta(c)$ signifikan, atau dengan mengalikan $\beta(a) \times(b) x$ $\beta(c)$ hasilnya positif maka dinamakan mediasi komplementer. Jika hasilnya negatif maka dinamakan mediasi kompetitif.

Apabila $\beta(a)$ dikalikan $\beta(b)$ signifikan dan $\beta(c)$ tidak signifikan, berarti memediasi secara tidak langsung.

Jika $\beta($ a) dikalikan $\beta($ b) hasilnya tidak signifikan dan $\beta(c)$ signifikan, berarti tidak memediasi secara langsung.

Jika $\beta($ a) dikali $\beta($ b) hasilnya tidak signifikan dan $\beta(c)$ tidak signifikan, maka tidak ada efek memediasi.

\section{Hasil Penelitian dan Pembahasan}

Hasil uji validitas dan reliabilitas keseluruhan data penelitian ini menunjukkan semua variabel item instrumen yang diteliti adalah valid. Nilai $r$ hitung tiap item variabel lebih besar dari $r$ tabel 0,100 untuk 386 responden dengan taraf signifikansi 5\%. Demikian pula hasil uji reliabilitas data, secara keseluruhan menunjukkan nilai crobach's alpha tiap variabel penelitian lebih besar dari standar 0,6 yakni nilai iklan yang dipersepsikan sebesar 0,825, citra destinasi sebesar 0,753, getok tular sebesar 0,697, dan minat wisata sebesar 0,630 sehingga ditarik kesimpulan bahwa tiap item pertanyaan adalah reliabel.

Adapun hasil deskriptif variabel persepsi iklan menunjukkan bahwa rata-rata keseluruhan item sebesar 3,90 yang artinya memiliki kecenderungan yang tinggi atau setuju adanya manfaat yang dirasakan dan pentingnya iklan wisata kota. Wisatawan menganggap 
setuju bahwa iklan di media memberikan informasi berharga dan terbaru (update) mengenai objek wisata di Kota Yogyakarta. Wisatawan merasa setuju bahwa iklan promosi wisata Kota Yogyakarta tampak menarik, bermanfaat dan berharga baginya serta dapat menikmati dan merasa terhibur. Secara keseluruhan, iklan di media merupakan sumber yang efektif untuk memberikan informasi tentang objek wisata di Kota Yogyakarta dan penting untuk diinformasikan.

Begitupun dengan variabel getok tular menunjukkan bahwa rata-rata keseluruhan sebesar 3,84 yang artinya memiliki kecenderungan yang tinggi atau setuju bahwa masyarakat untuk mendapatkan informasi wisata dengan berkomunikasi dengan orang yang tahu tentang objek wisata Kota Yogyakarta. Variabel citra destinasi menunjukkan rata-rata keseluruhan sebesar 4,05 yang artinya memiliki kecenderungan yang tinggi atau setuju tentang kesan Kota Yogyakarta bahwa Kota Yogyakarta memiliki banyak atraksi (kegiatan) budaya dan kesenian, situs bersejarah, tempat belanja, kuliner, dan arsitektur bangunan kota unik. Disisi lain, wisatawan menganggap Kota Yogyakarta memiliki kehidupan atau wisata malam yang menarik serta dari akses transportasi mudah, tersedia penginapan, kotanya aman dan terutama masyarakatnya ramah atau mudah berkomunikasi.

Pada variabel minat wisata menunjukkan hasil rata-rata keseluruhan sebesar 3,93 yang artinya memiliki kecenderungan yang tinggi atau setuju untuk melakukan wisata kota khususnya di Kota Yogyakarta di kemudian hari (di masa depan). Adapun hasil analisis regresi dan mediasi sebagai berikut:

\section{Pengaruh variabel nilai iklan yang dipersepsikan terhadap minat wisata kota Yogyakarta melalui citra destinasi}

Berdasarkan hasil uji regresi bertahap yang telah dilakukan, diperoleh hasil bahwa ada hubungan linear antara variabel nilai iklan yang dipersepsikan dengan variabel citra destinasi. Ada hubungan linear antara variabel nilai iklan yang dipersepsikan dengan variabel minat wisata kota dan ada hubungan linear antara variabel citra destinasi dengan variabel minat wisata kota. Ketiga hubungan tersebut signifikan dan berpengaruh positif.

Adapun hasil uji mediasi dapat dilihat pada tabel berikut:

Tabel 2. Hasil Uji Variabel Mediasi Persamaan 1

\begin{tabular}{|c|c|c|c|}
\hline \multirow{2}{*}{\multicolumn{2}{|c|}{ Variabel }} & $X$ & $\mathrm{M}$ \\
\hline & & Nilai iklan yang & Citra destinasi \\
\hline M & Citra destinasi (M) & 0,484 & \\
\hline $\mathrm{Y}$ & Minat wisata kota $(\mathrm{Y})$ & 0,290 & 0,388 \\
\hline & Langkah 1 ( $\mathrm{a} \times \mathrm{b})$ & 0,188 & \\
\hline & & Signifikan & \\
\hline & Langkah $2(\mathrm{a} \times \mathrm{b} \times \mathrm{c})$ & 0,054 & \\
\hline & Hasil Mediasi & $\begin{array}{c}\text { Mediasi } \\
\text { Komplementer }\end{array}$ & \\
\hline
\end{tabular}

Dari hasil uji mediasi yang telah dilakukan pada tabel 1, diketahui bahwa nilai iklan yang dipersepsikan berpengaruh secara langsung terhadap minat wisata Kota Yogyakarta dan secara tidak langsung juga berpengaruh terhadap minat wisata Kota Yogyakarta melalui citra 
destinasi sebagai variabel pemediasi. Berdasarkan pengembangan jenis-jenis mediasi yang dilakukan oleh Zhao et al (2010), maka citra destinasi dalam penelitian ini dapat dikatakan sebagai complementary mediation (mediasi komplementer) antara nilai iklan yang dipersepsikan dengan minat wisata Kota Yogyakarta, hal tersebut dapat dilihat dari hasil $\beta$ (a) $\mathrm{x} \beta(\mathrm{b}) \times \beta(\mathrm{c})$ hasilnya adalah positif.

Mengingat adanya efek pengaruh positif antara nilai iklan yang dipersepsikan di media terhadap citra destinasi Kota Yogyakarta dan berpengaruh secara langsung maupun tidak langsung terhadap minat wisata Kota Yogyakarta, penting bagi para pelaku marketer (marketing) pariwisata budaya perkotaan untuk melakukan dan meningkatkan iklan di media baik online maupun offline. Wisatawan menganggap iklan di media merupakan sumber yang efektif untuk memberikan informasi tentang objek wisata kota dan penting untuk diinformasikan. Selain itu, iklan promosi wisata di media mampu memberi nilai atau manfaat yang dirasakan seperti bahwa iklan promosi wisata Kota Yogyakarta di media tampak menarik, bermanfaat dan berharga bagi wisatawan. Iklan dinilai sebagai sarana informasi seperti memberikan informasi berharga dan terbaru (update) mengenai objek wisata di Kota Yogyakarta.

Nilai iklan merupakan indikator efektivitas sebuah iklan. Iklan mampu dirasakan berkat nilai yang tercipta yang berdampak pada perubahan pola pikir dan berperilaku. Bagi pemasar atau para perencana pemasaran sebaiknya mempertimbangkan efesien dan efektivitas dari penyampaian informasi tersebut. Iklan membantu objek wisata atau perusahaan dalam mempromosikan produk dan jasanya kepada calon wisatawan dan wisatawan. Iklan yang ditangkap masyarakat akan membentuk kesan atau citra dari destinasi yang dipromosikan yang berdampak kepada keinginan untuk mengunjungi.

\section{Pengaruh variabel getok tular terhadap minat wisata Kota Yogyakarta melalui citra destinasi}

Berdasarkan hasil uji regresi bertahap yang telah dilakukan, diperoleh hasil bahwa ada hubungan linear antara variabel getok tular dengan variabel citra destinasi. Ada hubungan linear antara variabel getok tular dengan variabel minat wisata kota dan ada hubungan linear antara variabel citra destinasi dengan variabel minat wisata kota. Ketiga hubungan tersebut signifikan dan berpengaruh positif.

Adapun hasil uji mediasi dapat dilihat pada tabel berikut:

Tabel 3. Hasil Uji Variabel Mediasi Persamaan II

\begin{tabular}{|c|l|c|c|}
\hline \multicolumn{2}{|c|}{ Variabel } & X & M \\
\cline { 3 - 3 } \multicolumn{2}{|c|}{} & $\begin{array}{c}\text { Getok tular } \\
\text { (X2) }\end{array}$ & $\begin{array}{c}\text { Citra destinasi } \\
\text { (M) }\end{array}$ \\
\hline M & Citra destinasi (M) & 0,343 & \multirow{2}{*}{0,388} \\
\hline Y & Minat wisata kota (Y) & 0,284 & \multirow{2}{*}{} \\
\hline & Langkah 1 (a x b) & 0,133 & \multirow{2}{*}{} \\
\hline & & Signifikan & \\
\hline & Langkah 2 (a x b x c) & 0,038 & Mediasi \\
& Hasil Mediasi & Komplementer & \\
\hline
\end{tabular}


Dari hasil uji mediasi yang telah dilakukan pada tabel 2, diketahui bahwa getok tular berpengaruh secara langsung terhadap minat wisata Kota Yogyakarta dan secara tidak langsung juga berpengaruh terhadap minat wisata Kota Yogyakarta melalui citra destinasi sebagai variabel pemediasi. Berdasarkan pengembangan jenis-jenis mediasi yang dilakukan oleh Zhao et al (2010), maka citra destinasi dalam penelitian ini dapat dikatakan sebagai complementary mediation (mediasi komplementer) antara getok tular dengan minat wisata kota Yogyakarta, hal tersebut dapat dilihat dari hasil $\beta(a) \times \beta(b) \times \beta(c)$ hasilnya adalah positif.

Dalam konteks pariwisata, getok tular atau word of mouth (wom) merupakan komunikasi antara dua orang atau lebih yang memberikan informasi dan pendapatnya mengenai produk, layanan jasa, atau perusahaan. Informasi dalam pariwisata berupa pelayanan jasa wisata, produk wisata, destinasi wisata dan sebagainya. Wisatawan setuju bahwa untuk mendapatkan informasi wisata dengan cara berkomunikasi dengan orang yang tahu atau paham tentang objek wisata Kota Yogyakarta. Upaya komunikasi dari mulut ke mulut tersebut menunjukkan bahwa persepsi mereka mendapatkan pengaruh dari luar yang membentuk kesan atau citra destinasi wisata. Dengan demikian, banyak wisatawan membutuhkan informasi dari orang lain sebagai bahan pertimbangan memilih destinasi wisata. Semakin sering dilakukan komunikasi getok tular maka akan semakin membentuk citra destinasi wisata yang berdampak pada tingkat minat wisata Kota Yogyakarta.

\section{Kesimpulan}

Nilai iklan yang dipersepsikan dan getok tular berpengaruh secara positif dan signifikan terhadap citra destinasi Kota Yogyakarta. Semakin tinggi nilai iklan yang dipersepsikan dan getok tular, maka akan semakin berdampak positif pada tingkat citra destinasi yang tinggi. Besar pengaruh nilai iklan yang dipersepsikan terhadap citra destinasi sebesar 23,3\% sedangkan besar pengaruh getok tular terhadap citra destinasi sebesar 11,5\%. Nilai iklan yang dipersepsikan dan getok tular berpengaruh secara positif dan signifikan terhadap minat wisata Kota Yogyakarta. Semakin tinggi nilai iklan yang dipersepsikan dan getok tular, maka akan berdampak positif terhadap tingkat minat wisata kota. Besar pengaruh nilai iklan yang dipersepsikan terhadap minat wisata kota sebesar 8,2\% sedangkan besar pengaruh getok tular terhadap minat wisata kota sebesar 7,8\%. Citra destinasi berpengaruh positif dan signifikan terhadap minat wisata Kota Yogyakarta. Semakin positif citra destinasi Kota Yogyakarta, maka akan berdampak positif terhadap tingkat minat wisata Kota Yogyakarta. Besar pengaruh citra destinasi Kota Yogyakarta terhadap minat wisata Kota Yogyakarta sebesar 14,8\%.

Hasil analisis variabel mediasi sesuai dengan pengembangan jenis mediasi yang dilakukan oleh Zhao et al., (2010), menunjukkan bahwa citra destinasi terbukti sebagai mediasi komplementar (complementary mediation) dalam memediasi hubungan antara nilai iklan yang dipersepsikan dan getok tular terhadap minat wisata Kota Yogyakarta.

Berdasarkan penelitian dan hasil analisis yang diperoleh maka disampaikan saran-saran penelitian sebagai berikut:

1. Bagi para peneliti yang mengajukan penelitian lebih lanjut dengan topik yang sama, sebaiknya ruang lingkup variabelnya lebih difokuskan lagi dan hendaknya instrumen 
penelitian lebih diperdalam dan dikembangkan sehingga kemampuan mengukurnya lebih baik.

2. Bagi peneliti selanjutnya dapat dilakukan penelitian dengan menggunakan variabel sosio demografi dan variabel promosi lainnya karena masih banyak faktor-faktor lain yang mempengaruhi citra destinasi dan minat wisata kota.

\section{Kepustakaan}

Ajzen. 1991. The Theory of Planned Behavior. Organizational Behavior and Human Decision Processes, 50, 179-211.

Al-Ekam, Jamal M.E., Mat, Nik K.N., Salleh, Salniza Md., Baharom, Norashikin B., Teh, Tuan R.B., Noh, Noor Aida., \& Hussain, Nor E., 2012. "The Influence of Trust, Advertising, Family on Intention and Actual Purchase of Lokal Brand in Yemen". American Journal of Economics June 2012, Special Issue: 64-68.

Damanik, Janianton. 2013. Pariwisata Indonesia Antara Peluang dan Tantangan. Pustaka Pelajar: Yogyakarta.

Di Pietro, Loredana, \& Di Virgilio, Francesca. 2011. "Social Network for the Choice of Tourist Destination: Attitude and Behavioural Intention". Journal of Hospitality and Tourism Technology Vol. 3 No. 1. 2012 pp 60-76 Emerald Grup Publishing.

Fakharyan M., Jalilvand M., Elyasi M., \& Mohammadi M. 2012. "The Influence of online word of mouth communication on tourists' attitudes toward Islamic destinations and travel intention: Evidence from Iran", Afr. Journal of Business Management, 6(38), 10381-10388. 2012.

Gibson, Heather J., Qi, Christene X., \& Zhang, James J. 2008. "Destination Image and Intent to Visit

China and the 2008 Beijing Olympic Games". Journal of Sport Management. 22, 427-450.

Jalilvand M.R., \& Samiei. N. 2012. "The Effect of Word of Mouth on Inbound Tourist' Decision for Travelling to Isfahan as a Tourism Destination in an Islamic Republic". Journal of Islamic Marketing, 3(1), 12-21. 2012.

Kedaulatan Rakyat. 2015. 60 persen, Pariwisata Indonesia Bergantung Budaya. Jakarta. Senin, 23 November 2015 hal. 11.

Kompas. 2015. Wisata menjadi Kebutuhan Publik. Kompas Gramedia. 3 November 2015. Http:print.kompas.com/baca/2015/11/03/Wisata-Menjadi-Kebutuhan-Publik.

Lopes, S.D.F. 2011. Destination Image: origins, Developments and Implications. Journal PASOS. Revista de Turismo y Patrimonio Cultural. ISSN 1695-7121.

Madasu, Pardhasaradhi. 2013. Social Media Marketing and Promotion of Tourism. Management Insight SMS Varanasi. Vol. IX, No. 1 June 2013.

Miao, Yulin. 2014. The Influence of Electronic-WOM on Tourist' Behavioral Intention to Choose a Destination: A Case of Chinese Tourists Visiting Thailand. AUGSB E-Journal.

Mohammed, A.R.J., Zahari, M.S.M., Talib, S.A., \& Suhaimi, Mohd Z. 2014. The Causal Relationships between Destination Image, Tourist Satisfaction and Revisit Intention: A Case of the United Arab Emirates. International Journal of Social, Behavioral, Educational, Economic, Business and Industrial Engineering Vol. 8, No: 10. 2014.

Wang, Xiaoli. 2012. Atitude toward the Advertising and Subjective Norm on Purchase Intention: A Case of Television Advertising of Beauty and Personal Care Product in Bangkok. Thesis. University of Thai Chamber of Commerce.

Zarrad H., \& Debabi M. 2015. Analyzing the Effect of Electronik Word of Mouth on Tourists' Attitude toward Destination and Travel Intention. International Research Journal of Social Sciences. ISSN 2319-3565 Vol. 4(4), 53-60, April (2015). 